\title{
Application of the Problem Based Learning Model to Improve Critical Thinking Skills for Grade IV Elementary School Students
}

\section{Elyana Rahmawati}

SD Negeri 1 Muryolobo

elyana.rahmawati1@gmail.com

\section{Article History}

received 3/12/2020

revised $17 / 12 / 2020$

accepted 31/12/2020

\begin{abstract}
This study aims to improve critical thinking skills through the application of a Problem Based Learning based. This research is a classroom action research conducted in two cycles with planning, implementation, observation, and reflection stages. Data collection instruments use question instruments, observation sheets, documentation, and field notes. The subject of the study was the fourth grade students of SDN 1 Muryolobo. The results showed an increase in critical thinking skills as indicated by the data in the pre cycle of $42 \%$, in the first cycle increased by $67,23 \%$, and in the second cycle increased by $80,72 \%$. Increasing critical thinking skills also affects the students learning outcomes. This is indicated by the learning outcomes on Indonesian language in pre cycle, cycle I, and cycle II, are $45 \%, 68 \%$, and $81 \%$. Furthermore, the learning outcomes of IPS in pre cycle, cycle I, and cycle II are $36 \%, 63 \%$, and $81 \%$.
\end{abstract}

Keywords: critical thinking skills, problem based learning, elementary school

\begin{abstract}
Abstrak
Penelitian ini bertujuan untuk meningkatkan keterampilan berpikir kritis melalui model Problem Based Learning. Penelitian ini merupakan penelitian tindakan kelas yang dilaksanakan dua siklus dengan tahp perencanaan, pelaksanaan, pengamatan, dan refleksi. Instrumen pengumpulan data menggunakan instrumen soal, lembar observasi, dokumentasi, dan catatan lapangan. Subjek penelitian adalah peserta didik kelas 4 SDN 1 Muryolobo. Hasil penelitian menunjukkan adanya peningkatan keterampilan berpikir kritis yang ditunjukkan dengan data pada prasiklus sebesar $42 \%$, pada siklus I meningkat $69,83 \%$, dan pada siklus II meningkat sebesar $80,72 \%$. Peningkatan keterampilan berpikir kritis berdampak pula pada ketuntasan hasil belajar pada muatan Bahasa Indonesia secara berturut-turut pada pra siklus, siklus I, dan siklus II yaitu $45 \%, 68 \%$, dan $81 \%$. Selanjutnya muatan IPS secara berturut-turut pada prasiklus, siklus I, siklus II yaitu $36 \%, 63 \%$, dan $81 \%$.
\end{abstract}

Kata kunci: keterampilan berpikir kritis, problem based lerning, sekolah dasar

Social, Humanities, and Education Studies (SHEs): Conference Series https://jurnal.uns.ac.id/shes

p-ISSN 2620-9284

e-ISSN 2620-9292 


\section{PENDAHULUAN}

Pendidikan di Indonesia sekarang mengunakan kurikulum 2013 yang mengacu pada pembelajaran tematik integratif. Mawardi (2014:109) menjelaskan bahwa pembelajaran tematik integratif merupakan pembelajaran yang memadukan beberapa muatan pelajaran dalam suatu tema tertentu sebagai pemersatu. Pembelajaran tematik integratif mendorong peserta didik untuk menemukan sendiri pengetahuan yang akan dipelajari dan dikaitkan dengan pengetahuan yang sudah dimiliki sebelumnya dengan cara memanfaatkan masalah-masalah sosial dalam lingkungan masyarakat yang majemuk lengkap di kehidupan sehari-hari peserta didik.

Tuntutan pembelajaran tematik integratif dilakukan pergeseran dari pembelajaran yang menekankan pada keterampilan berpikir tingkat rendah ke pembelajaran yang menekankan pada keterampilan berpikir tingkat tinggi atau keterampilan berpikir kritis. Menurut Walker berpikir kritis merupakan suatu proses yang dilalui dari proses pemecahan masalah dan kolaborasi dengan tujuan agar peserta didik memperoleh pengetahuan baru (Redhana, 2012). Pengetahuan yang diberikan kepada peserta didik ditekankan pada pertanyaan yang membutuhkan pemikiran mendalam, bukan sekedar hafalan, yaitu dengan mengembangkannya secara HOTS (High Order Thinking Skills).

Keterampilan berpikir kritis sangat perlu dilatih karena keterampilan tersebut tidak begitu saja dimiliki oleh peserta didik (Satwika dan Khoirunnisa, 2018). Keterampilan berpikir kritis harus terus menerus dilatih dan disengaja agar dapat berkembang ke arah yang potensial. Redhana (2012) mengungkapkan bahwa keterampilan berpikir kritis dapat diperoleh dari pembelajaran yang memberikan kesempatan kepada peserta didik dalam memecahkan masalah. Oleh karena itu, dalam pembelajaran tematik integratif hendaknya diawali dengan pengenalan masalah yang berkaitan dengan kehidupan sehari-hari di lingkungan sekitar mereka, sehingga pembelajaran bersifat kontekstual dan peserta didik dapat menemukan sendiri konsep yang dipelajarinya. Dengan demikian, peserta didik tidak semata-mata memahami konsep yang sudah ada, tetapi mampu berproses untuk mendapatkan konsep tersebut. Selain itu, pembelajaran tidak hanya memperoleh pengetahuan saja, akan tetapi menanamkan sikap yang dapat diterapkan dalam pemecahan masalah kehidupan sehari-hari, serta keterampilan berpikir kritis terkait dengan pemecahan masalah tersebut.

Berdasarkan hasil observasi, di SDN 1 Muryolobo sudah menerapkan kurikulum 2013 akan tetapi pada proses pembelajaran guru masih mendominasi pembelajaran. Hal ini terlihat ketika menyampaikan materi ajar pada proses pembelajaran, guru masih sering menggunakan metode ceramah yang menyebabkan peserta didik menjadi kurang aktif dan tidak kreatif. Kemampuan berpikir kritis peserta didik juga tergolong rendah. Soal-soal evaluasi yang diberikan masih terfokus pada aspek kognitif tingkat rendah, belum berorientasi untuk mengembangkan kemampuan berpikir kritis peserta didik, sehingga kemampuan berpikir kritis peserta didik kurang berkembang. Kemampuan peserta didik dalam memahami materi pelajaran sudah cukup baik. Namun, rata-rata peserta didik belum mampu memahami secara mendalam materi pelajaran yang disampaikan karena peserta didik cenderung hanya menghafalkan materi yang diberikan daripada mengembangkan daya pikir. Proses pembelajaran yang dilakukan guru sudah menggunakan model dan media pembelajaran yang sesuai, namun belum mampu memunculkan peningkatan keterampilan berpikir kritis dari beberapa peserta didik. Selain itu, pembelajaran yang dilakukan belum menyajikan situasi permasalahan sehingga peserta didik kurang terlatih untuk berpikir kritis dalam memecahkan masalah.

Untuk mengatasi permasalahan tersebut, maka diperlukan sebuah inovasi dalam pembelajaran. Peneliti memberikan alternatif solusi yakni penerapan model pembelajaran yang dapat membantu peserta didik untuk meningkatkan ketrampilan berpikir kritis. Model pembelajaran yang akan diterapkan yakni model Problem Based 
Learnig, yang merupakan salah satu model pembelajaran inovatif yang dapat mengasah ketrampilan berpikir kritis peserta didik. Ward dan Stepien menyatakan bahwa Problem Based Learning merupakan model pembelajaran yang melibatkan peserta didik untuk menggunakan tahap-tahap metode ilmiah dalam memecahkan suatu masalah sehingga peserta didik dapat memperoleh pengetahuan berdasarkan permasalahan tersebut dan sekaligus mengembangkan keterampilan untuk memecahkan masalah (Ngalimun, 2014). Menurut Arends (2013) model PBL adalah model pembelajaran dengan pendekatan pembelajaran siswa pada masalah autentik, sehingga siswa bisa menyusun pengetahuannya sendiri, menumbuhkan keterampilan yang lebih tinggi dan inkuiri, memandirikan siswa, serta meningkatkan kepercayaan diri. Model Problem Based Learning ini lebih menekankan pada peserta didik dalam memecahkan suatu masalah. Selain itu peserta didik diarahkan untuk berpikir kritis.Dengan demikian kemampuan memecahkan masalah dan keterampilan berpikir kritis peserta didik dapat berkembang.

Tahapan-tahapan dalam Problem Based Learning yang dilaksanakan secara sistematis dapat meningkatkan kemampuan peserta didik dalam menguasai pengetahuannya. Tahapan penyelesaian masalah tersebut dilaksanakan dalam lima langkah seperti yang dikemukakan oleh Arends (2013) yaitu mengarahkan peserta didik kepada masalah, mempersiapkan peserta didik untuk belajar, membantu penelitian mandiri dan kelompok, mengembangkan dan menyajikan artefak dan benda pajang, serta menganalisis dan mengevaluasi proses pemecahan masalah. Warsono dan Hariyanto (2013) menyatakan bahwa Problem Based Learning diterapkan dalam pembelajaran karena memberikan banyak kelebihan, diantaranya yaitu permasalahan disajikan pada awal pembelajaran, kemudian peserta didik memperdalam pengetahuannya tentang apa yang telah diketahui dan yang perlu diketahui untuk memecahkan masalah, masalah yang disajikan sebagai fokus pembelajaran diselesaikan melalui kerja kelompok sehingga menambah pengalaman peserta didik dalam hal kerjasama dan interaksi dalam kelompok].

Penelitian yang mendukung antara lain penelitian yang dilakukan oleh Vera \& Wardani (2018) dan Budiarti, I. \& Airlanda, G. S. (2019) menunjukkan bahwa pembelajaran dengan model Problem Based Learning dapat meningkatkan keterampilan berpikir kritis peserta didik. Kedua penelitian tersebut memberikan hasil pada ketrampilan berpikir kritis yang mengalami peningkatan melalui model Problem Based Learning. Oleh karena itu, peneliti menerapkan model Problem Based Learning untuk mengatasi permasalahan yang sama yaitu pada ketrampilan berpikir kritis. Hal ini dikarenakan pembelajaran berbasis masalah membantu peserta didik dalam berpikir kritis untuk membangun sendiri pengetahuannya berdasarkan pengalaman belajar. Hasil penelitian ini diharapkan dapat memberikan manfaat khususnya dalam bidang pendidikan, yaitu dengan menerapkan model Problem Based Learning sebagai salah satu cara untuk meningkatkan keterampilan berpikir kritis dalam pembelajaran tematik.

\section{METODE}

Penelitian ini merupakan penelitian tindakan kelas (classroom action research) dengan tujuan untuk meningkatkan keterampilan berpikir kritis peserta didik. Penelitian tindakan kelas merupakan penelitian yang bertujuan untuk meningkatkan kualitas pembelajaran dengan cara memecahkan masalah-masalah aktual mengenai pembelajaran di kelas (Arikunto: 2010). Penelitian ini dilakukan di kelas 4 SDN 1 Muryolobo, Kecamatan Nalumsari, Kabupaten Jepara semester 2 tahun ajaran 2019/2020. Adapun subjek penelitian berjumlah 22 peserta didik, yang terdiri atas 8 peserta didik laki-laki dan 14 peserta didik perempuan. Penelitian Tindalan Kelas ini dilaksanakan dalam dua siklus.

Teknik pengumpulan data yang digunakan adalah teknik tes dan nontes. Teknik tes digunakan untuk mengumpulkan data kuantitatif yang berupa pemberian tes tertulis 
berbentuk isian singkat dan uraian kepada peserta didik. Pengumpulan data dalam teknik nontes diperoleh menggunakan dokumentasi dan catatan lapangan. Teknik analisis data kuantitatif yang digunakan dalam penelitian ini adalah teknik deskriptif komparatif, yaitu membandingkan nilai tes tertulis pada setiap siklusnya. Sedangkan data kualitatif dianalisis menggunakan teknik analisis deskriptif kuantitatif berdasarkan aspek-aspek yang menjadi fokus analisis menurut pengelompokan kategori untuk memperoleh simpulan. Penelitian ini dikatakan berhasil apabila hasil tes peserta didik mencapai nilai KKM (70) secara individual dan mencapai $\geq 80 \%$ secara klasikal. Sedangkan keterampilan berpikir kritis dikatakan berhasil apabila skor rata-rata keterampilan berpikir kritis peserta didik mencapai $80 \%$ secara klasikal dan meningkat dengan predikat minimal baik (minimal 2,51; skala 4).

\section{HASIL DAN PEMBAHASAN}

Pengamatan dilakukan saat pembelajaran pada tema 7 Indahnya Keragaman di Negeriku Subtema 3 Indahnya Persatuan dan Kesatuan Negeriku Pembelajaran 4 dan menganalisis soal evaluasi peserta didik. Hasil yang diperoleh dari hasil pengamatan yakni pembelajaran yang dilakukan guru sudah menggunakan model dan media pembelajaran yang sesuai, namun belum mampu memunculkan peningkatan keterampilan berpikir kritis dari beberapa peserta didik. Kemampuan peserta didik dalam memahami materi pelajaran sudah cukup baik. Namun, rata-rata peserta didik belum mampu memahami secara mendalam materi pelajaran yang disampaikan karena peserta didik cenderung hanya menghafalkan materi yang diberikan daripada mengembangkan daya pikir. Hal ini dapat dilihat pada tabel berikut.

Tabel 1. Ketuntasan hasil belajar kondisi pra siklus

\begin{tabular}{cccccc}
\hline \multirow{2}{*}{ No. } & \multirow{2}{*}{ Kategori } & \multicolumn{2}{c}{ Bahasa Indonesia } & \multicolumn{2}{c}{ IPS } \\
\cline { 3 - 6 } & & $\begin{array}{c}\text { Banyak } \\
\text { Siswa }\end{array}$ & Persentase & $\begin{array}{c}\text { Banyak } \\
\text { Siswa }\end{array}$ & Persentase \\
\hline 1. & Tuntas & 10 & $45 \%$ & 8 & $36 \%$ \\
2. & Tidak Tuntas & 12 & $55 \%$ & 14 & $64 \%$ \\
Total & & 22 & $100 \%$ & 22 & $100 \%$ \\
\hline
\end{tabular}

Tabel 1 menunjukkan ketuntasan hasil belajar pada kondisi pra siklus dapat dilihat dari hasil belajar rata-rata nilai yang diperoleh peserta didik pada muatan pelajaran Bahasa Indonesia dan IPS belum mencapai ketuntasan klasikal sebesar > $80 \%$. Atas dasar tersebut, maka dapat disimpulkan bahwa hasil belajar muatan Bahasa Indonesia dan IPS peserta didik kelas 4 SDN 1 Muryolobo masih perlu ditingkatkan.

Setelah melakukan refleksi, peneliti merencanakan alternatif pemecahan masalah.Peneliti menyusun perangkat pembelajaran menggunakan model Problem Based Learning. Penelitian ini menganalisis penerapan model Problem Based Learning terhadap keterampilan berpikir kritis peserta didik. Pada penelitian ini, keterampilan berpikir kritis dianalisis berdasarkan lima indikator berpikir kritis yang dikemukakan oleh Robert Ennis, yaitu memfokuskan pertanyaan, mengobservasi dan mempertimbangkan laporan observasi, menentukan suatu tindakan, menginduksi, dan mengidentifikasi asumsi (Ennis dalam Qurniati, 2015). Kelima indikator keterampilan berpikir kritis yang direncanakan dapat terlaksana dengan baik. Hal ini terbukti dengan adanya peningkatan keterampilan berpikir kritis peserta didik setelah menggunakan model Problem Based Lerning. Peningkatan keterampilan kritis peserta didik kelas IV SDN 1 Muryolobo dapat dilihat pada tabel di bawah ini. 
Tabel 2. Keterampilan berpikir kritis peserta didik kelas IV SDN 1 Muryolobo

\begin{tabular}{|c|c|c|c|c|}
\hline \multirow{2}{*}{ No } & \multirow[b]{2}{*}{ Indikator } & \multicolumn{3}{|c|}{ Rerata Skor } \\
\hline & & $\begin{array}{c}\text { Pra } \\
\text { Siklus }\end{array}$ & $\begin{array}{c}\text { Siklu } \\
\text { s l }\end{array}$ & $\underset{\text { II }}{\text { Siklus }}$ \\
\hline 1 & Memfokuskan pertanyaan & 2,45 & 2,75 & 3,00 \\
\hline 2 & $\begin{array}{lr}\text { Mengobservasi } & \text { dan } \\
\text { mempertimbangkan } & \text { laporan } \\
\text { observasi } & \end{array}$ & 2,36 & 2,90 & 3,25 \\
\hline 3 & Menentukan suatu tindakan & 2,59 & 3,00 & 3,50 \\
\hline 4 & Menginduksi & 2,36 & 2,95 & 3,15 \\
\hline 5 & Mengidentifikasi asumsi & 2,41 & 3,00 & 3,20 \\
\hline & Jumlah & 12,17 & 14,6 & 16,10 \\
\hline Rat & rata & 2,43 & 2,73 & 3,22 \\
\hline Per & entase kelulusan & $42 \%$ & $\begin{array}{c}69,83 \\
\%\end{array}$ & $\begin{array}{c}80,72 \\
\%\end{array}$ \\
\hline Kat & yori & $\begin{array}{c}\text { Kurang } \\
\text { Baik }\end{array}$ & Baik & $\begin{array}{l}\text { Sang } \\
\text { at } \\
\text { Baik }\end{array}$ \\
\hline
\end{tabular}

Tabel 2 menunjukkan hasil penelitian peningkatan keterampilan berpikir kritis setelah dilaksanakan pembelajaran menggunakan model Problem Based Learning. Kondisi pra siklus menunjukkan bahwa rata-rata keterampilan berpikir kritis peserta didik yaitu 2,43 dengan kriteria kurang baik dan terdapat sebanyak $42 \%$ peserta didik yang memperoleh kriteria minimal baik. Pada siklus I keterampilan berpikir kritis peserta didik meningkat. Hal ini ditunjukkan dengan rata-rata skor yang meningkat menjadi 2,73 dengan kriteria baik dan sebanyak 69,83\% peserta didik yang memperoleh kriteria minimal baik. Pada siklus I rata-rata skor sudah mencapai indikator keberhasilan yaitu dengan kriteria minimal baik, namun perolehan ketuntasan klasikal peserta didik belum terpenuhi sehingga dilaksanakan refleksi untuk perbaikan siklus berikutnya. Setelah diadakan refleksi terhadap pelaksanaan siklus I, hasil keterampilan berpikir kritis pada siklus II mencapai angka rata-rata 3,22 dengan kategori sangat baik dan peserta didik yang mendapatkan kriteria nilai minimal baik sebesar $80,72 \%$. Perolehan hasil keterampilan berpikir kritis pada siklus II meningkat kembali, peserta didik mendapatkan kategori minimal baik sebanyak 80,72\% dengan rata-rata skor 3,22.

Berdasarkan hasil di atas dapat disimpulkan bahwa melalui penerapan model Problem Based Learning dapat meningkatkan keterampilan berpikir kritis peserta didik. $\mathrm{Hal}$ ini sejalan dengan penelitian yang dilakukan oleh Yakob (2017) yang menyatakan bahwa pembelajaran berbasis kearifan lokal lebih berorientasi pada peserta didik dan memandangnya sebagai subjek dalam pembelajaran sehingga keterampilan berpikir kritis peserta didik dapat meningkat.

Peningkatan keterampilan berpikir kritis memiliki pengaruh terhadap meningkatnya hasil belajar peserta didik. Pada penelitian ini peserta didik diberikan dua kali tes yaitu tes formatif siklus I dan tes formatif siklus II dengan bentuk soal tes berupa isian singkat dan uraian. Sedangkan hasil belajar pra siklus diperoleh dari studi dokumentasi hasil Penilaian Tengah Semester peserta didik. Hasil belajar setiap siklus pada penelitian ini mengalami peningkatan. Hasil belajar peserta didik secara rinci disajikan dalam tabel 3. 
SHEs: Conference Series 3 (4) (2020) $104-110$

Tabel 3. Ketuntasan hasil belajar peserta didik kelas IV SDN 1 Muryolobo

\begin{tabular}{|c|c|c|c|c|c|c|c|c|c|c|c|c|}
\hline \multirow{3}{*}{ Kategori } & \multicolumn{4}{|c|}{ Pra Siklus } & \multicolumn{4}{|c|}{ Siklus I } & \multicolumn{4}{|c|}{ Siklus II } \\
\hline & \multicolumn{2}{|r|}{$\mathrm{BI}$} & \multicolumn{2}{|c|}{ IPS } & \multicolumn{2}{|r|}{$\mathrm{Bl}$} & \multicolumn{2}{|c|}{ IPS } & \multicolumn{2}{|c|}{$\mathrm{Bl}$} & \multicolumn{2}{|c|}{ IPS } \\
\hline & $f$ & $\%$ & $f$ & $\%$ & $f$ & $\%$ & $f$ & $\%$ & $f$ & $\%$ & $f$ & $\%$ \\
\hline Tuntas & 10 & $45 \%$ & 6 & $27 \%$ & 15 & $68 \%$ & 16 & $73 \%$ & 18 & $82 \%$ & 19 & $86 \%$ \\
\hline $\begin{array}{l}\text { Tidak } \\
\text { Tuntas }\end{array}$ & 12 & $55 \%$ & 16 & $73 \%$ & 7 & $32 \%$ & 6 & $27 \%$ & 4 & $18 \%$ & 3 & $14 \%$ \\
\hline Total & 22 & $\begin{array}{c}100 \\
\%\end{array}$ & 22 & $\begin{array}{c}100 \\
\%\end{array}$ & 22 & $\begin{array}{c}100 \\
\%\end{array}$ & 22 & $\begin{array}{c}100 \\
\% \\
\end{array}$ & 22 & $\begin{array}{c}100 \\
\%\end{array}$ & 22 & $\begin{array}{c}100 \\
\%\end{array}$ \\
\hline
\end{tabular}

Berdasarkan data pada tabel di atas, ketuntasan belajar peserta didik meningkat dari pra siklus, siklus I, dan siklus II. Sebelum pelaksanaan tindakan atau pra siklus, ketuntasan hasil belajar pada muatan Bahasa Indonesia sebesar 45\%, kemudian meningkat menjadi $68 \%$, dan mengalami peningkatan kembali pada siklus II sebesar $82 \%$. Sementara itu, ketuntasan hasil belajar muatan IPS pada pra siklus sebesar $27 \%$, kemudian pada siklus I meningkat menjadi $73 \%$ dan meningkat kembali pada siklus II menjadi $86 \%$.

Hasil keterampilan berpikir kritis peserta didik melalui penerapan model Problem Based Learning berdasarkan data yang telah dipaparkan di atas terbukti dapat meningkat dan mencapai indikator keberhasilan. Hal tersebut berdampak pada hasil tes formatif yang semakin meningkat setiap siklusnya. Hal ini sejalan dengan penelitian yang dilakukan oleh Bachtiar (2014) dan Nafiah \& Suyanto (2014) yang mengemukakan bahwa model pembelajaran Problem Based Learning dapat meningkatkan kemampuan berpikir kritis dan berdampak terhadap hasil belajar kognitif peserta didik.

Keterampilan berpikir kritis dan hasil belajar peserta didik ditingkatkan melalui pelaksanaan pengalaman belajar yang dapat membantu peserta didik melakukan aktivitas belajarnya secara langsung, seperti pada pembelajaran dengan penerapan model Problem Based Learning. Hal ini sejalan dengan pendapat Rahayu, Sapri, \& Alexon (2017) yang menyatakan bahwa peningkatan keterampilan berpikir kritis dan prestasi belajar peserta didik dapat diupayakan melalui model pembelajaran Problem Based Learning yang disesuaikan dengan materi, karakter, dan kebutuhan peserta didik.

\section{SIMPULAN}

Penerapan model Problem Based Learning berhasil meningkatkan keterampilan berpikir kritis yang berdampak pada hasil belajar peserta didik kelas 4 SDN 1 Muryolobo. Hal tersebut ditunjukkan oleh perolehan skor keterampilan berpikir kritis yang mengalami peningkatan dari pra siklus, siklus I, dan siklus II. Dari 22 peserta didik, rata-rata keterampilan berpikir kritis pra siklus sebesar $42 \%$, kemudian pada siklus I meningkat menjadi $69,83 \%$, dan meningkat kembali pada siklus II menjadi $80,72 \%$ yang telah memenuhi indikator keberhasilan yang telah ditetapkan. Peningkatan hasil belajar ditunjukkan oleh besarnya persentase hasil belajar yang mencakup dua muatan yaitu Bahasa Indonesia dan IPS. Pada muatan Bahasa Indonesia, terdapat peningkatan ketuntasan hasil belajar dari pra siklus sebesar $45 \%$, siklus I dengan ketuntasan $68 \%$, kemudian menjadi $81 \%$ pada siklus II. Selanjutnya pada muatan IPS terdapat peningkatan ketuntasan hasil belajar dari pra siklus sebesar $36 \%$, siklus I dengan ketuntasan $63 \%$, kemudian menjadi $81 \%$ pada siklus II.

Berdasarkan simpulan di atas, Problem Based Learning dapat diterapkan dalam pembelajaran tematik integratif di sekolah dasar karena dapat menjadi alternatif bagi guru dalam mencapai tuntutan Kurikulum 2013. 
DAFTAR PUSTAKA

Arends, Richard I. (2013). Belajar untuk Mengajar: Learning to Teach Buku 2. Jakarta: Salemba Humanika.

Arikunto, Suharsimi, dkk. (2010). Penelitian Tindakan Kelas. Jakarta: Bumi Aksara.

Bachtiar, Suhaedir. (2014). Peningkatan Kemampuan Berpikir Kritis dan Hasil Belajar Kognitif Melalui Model Pembelajaran Problem Based Learning (PBL) Pada Materi Sistem Ekskresi Siswa Kelas IX1 Di Smp Negeri 2 Batang. In Prosiding Seminar Nasional 2014 Pemberdayaan Pendidik Abad 21 SMK Negeri 13 Kota Malang.

Mawardi, M. (2014). Pemberlakuan Kurikulum SD/MI Tahun 2013 dan Implikasinya Terhadap Upaya Memperbaiki Proses Pembelajaran Melalui PTK. Scholaria: Jurnal Pendidikan dan Kebudayaan, 4(3), 107-121. Diakses dari: https://doi.org/10.24246/j.scholaria.2014.v4.i3.p107-121

Nafiah, Y. N., \& Suyanto, W. (2014). Penerapan model problem-based learning untuk meningkatkan keterampilan berpikir kritis dan hasil belajar siswa. Jurnal Pendidikan Vokasi, 4(1), 125-143. Diakses dari https://journal.uny.ac.id/index.php/jpv/article/viewFile/2540/2098

Ngalimun. 2014. Strategi dan Model Pembelajaran. Yogyakarta: Aswaja Pressindo.

Qurniati, D., \& Andayani, Y. (2015). Peningkatan Keterampilan Berpikir Kritis melalui Model Pembelajaran Discovery Learning. Jurnal Penelitian Pendidikan IPA, 1(2). Diakses dari https://doi.org/10.29303/jppipa.v1i2.20

Rahayu, S., Sapri, J., \& Alexon, A. (2017). The Implementation of Problem Based Learning (Pbl) for Improving Critical Thinking and Student's Achievement. Jurnal Ilmiah Teknologi Pendidikan, 7(2), 98-110. Diakses dari https://ejournal.unib.ac.id/index.php/diadik/article/view/3688/1933

Redhana, I. W. (2012). Model pembelajaran berbasis masalah dan pertanyaan socratik untuk meningkatkan keterampilan berpikir kritis siswa. Cakrawala Pendidikan, (3). Diakses dari: https://journal.uny.ac.id/index.php/cp/article/view/1136

Satwika, Y. W., Laksmiwati, H., \& Khoirunnisa, R. N. (2018). Penerapan Model Problem Based Learning untuk Meningkatkan Kemampuan Berfikir Kritis Mahasiswa. Jurnal Pendidikan (Teori dan Praktik), 3(1), 7-12. Diakses dari https://journal.unesa.ac.id/index.php/jp/article/view/1818

Vera, K., \& Wardani, K. W. (2018). Peningkatan keterampilan berfikir kritis melalui model problem based learning berbantuan audio visual pada siswa kelas IV SD. JARTIKA: Jurnal Riset Teknologi dan Inovasi Pendidikan, 1(2), 33-45. Diakses dari http://journal-litbang-rekarta.co.id/index.php/jartika/article/view/4

Warsono dan Hariyanto. (2013). Pembelajaran Aktif. Jakarta: Remaja Rosdakarya.

Yakob, M. \& Saputra, H. (2017). Pembelajaran Experiential Learning Berbasis Kearifan Lokal untuk Meningkatkan Keterampilan Berpikir Kritis Mahasiswa Calon Guru Fisika. In Prosiding Seminar Nasional MIPA III Unsyiah Conferences. 